\title{
Is There a Causality Between Emigration and Other Mobility Factors? A Panel VAR Model Approach for Baltic and Scandinavian Countries
}

\author{
${ }^{1}$ Kaunas University of technology \\ K. Donelaicio st. 20. LT-44309, Kaunas, Lithuania \\ E-mail.a.mihi@ktu.edu \\ ${ }^{2}$ Granada University \\ Campus Cartuja, Granada, 18071, Spain \\ E-mail.ecuenca@ugr.es \\ ${ }^{3}$ University of Las Palmas de Gran Canaria \\ Campus de Tafira, Edificio Departamental de Empresariales 35017 \\ Las Palmas de Gran Canaria (Spain) \\ E-mail.maria.martel112@alu.ulpgc.es \\ cross $^{\text {ref }}$ http://dx.doi.org/10.5755/j01.ee.27.3.14395
}

Antonio Mihi-Ramirez¹, Eduardo Cuenca-Garcia², Maria Jose Miranda-Martel ${ }^{3}$

\begin{abstract}
This paper analyzes causality relationships between mobility factors such as emigration, trade balance, export, foreign direct investment and remittances received. A panel VAR model is developed for a group of Scandinavian and Baltic countries (7) to test for causalities between those mobility factors in 1999-2014. The presence of cointegration is tested using the Fisher-Johansen cointegration test. The Wald test is also employed to provide evidence on whether there are any causalities between variables. The results showed no long run associationship between mobility factors and the presence of only one causality relationship, namely the causality running from remittances received to emigration. In this sense remittances usually help to trigger an initial or more massive migration in the first place, and later, the persistence of imbalances or migrants networks contribute to the migration process's continuation.

Therefore, as an effective migration policy in a short run we recommend promotion and the use of remittances received in activities related to improve productivity of any sector. This is to avoid higher migration and also to reduce poverty in sending countries. In addition, when the imbalances are reduced, such policies promote family reunifications so that to reinforce migrant networks.
\end{abstract}

Keywords: Emigration, Trade, Exports, Foreign Direct Investment, Remittances Received, VAR Model.

\section{Introduction}

International trade has gradually increased in the second half of the 20th century, and when it comes to foreign direct investment (FDI), migration and remittances, the growth has been even bigger (Aubry, Kugler \& Rapoport, 2012). Emigration, trade, foreign direct investment (FDI) and remittances received are very important for every economy and they are all considered substitutes or complements (Mundel, 1957; Markusen, 1983; Massey, 1988; Schiff, 1994; Jennissen, 2004; Schiff, 2006; Akkoyunlu, 2009; Bijak, 2010; Kurekova, 2011; Metelski \& Mihi-Ramirez, 2015).

In this sense, the neo-classical economic migration theory argues that changes in trade balance (exports imports), FDI and remittances make people move from one country to another (Massey, 1988). Take for instance Schiff (1994), who indicated that more remittances received financed migrations' costs incurred by prospective migrants, which in turn also ultimately led to increase those remittances.

Also, the migration systems theory posits that factors such as export, FDI and remittances contribute to connection and integration of the sending and receiving countries in a relatively stable manner (Jennissen, 2004; Castles \& Miller, 2009). For instance, FDI exerts an important and direct effect on the labor market and the growth, with the latter leading to a significant change of migration flow in the form of an indirect impact (Sanderson \& Kentor, 2008).

However, in terms of the Heckscher-Ohlin conceptual framework, these international mobility factors are regarded complements (Markusen, 1983; Schiff, 2006). Similarly to the exchange in foreign trade emigration is the result of the exchange of production resources, and more specifically, of capital and labor. It can also be understood that international trade is a sort of supplement for capital movements (also for the FDI) and migration flows (Schiff, 1994; Taylor, 1996).

Despite the relevance of the interaction of these factors for international migration there is actually lack of studies in this field (Jennissen, 2004; De Haas, 2011). Furthermore, there are very few works analyzing causality between emigration and mobility factors (De Haas, 2011), and they mostly focus on cross-sectional or time series analyses, which does not reflect the interactions and 
connections between them and migration flows (Metelski \& Mihi-Ramirez, 2015).

For all these reasons the aim of this research is to check whether there are any causalities between different combinations of mobility factors that are subject of our study (emigration, trade balance, FDI and remittances paid). Thus, the objective of this research is to study reciprocal relations between emigration, exports, foreign direct investment (FDI) and remittances paid. We would like to spot whether there are any long run or short run causalities between mobility factors. It could be formulated through the following scientific questions: Are emigration and other mobility factors the substitutes in a long/short run? Or on the contrary, is it just a complementary association?

This study uses data that consist of annual observations for countries that lie in an important and well developed European region and that are closely related with each other, such as Scandinavian and Baltic area countries (Sweden, Norway, Denmark, Finland, Lithuania, Latvia and Estonia). The data is spanning the most recent period, i.e. from 1999 to 2014. All models employed in this study are vector autoregression models (VARs) and they capture linear interdependencies among multiple time series. Causality Wald test is also employed to provide evidence that such a reciprocal type of relationships exists.

This paper is structured as follows: in its first part the theoretical approach is explained, which covers the review of different migration theories and their contributions to the field of mobility factors' causalities. The methodology employed in this study is described and the results are explained in the subsequent part. Finally, the conclusions are set out.

\section{Background}

The flow of international labor migrants brings certain changes in both the destination and origin countries (Jennissen, 2004). According to the neo-classical economic migration theory countries (or regions) with low relative labor to capital levels usually also have higher relative wages, whereas the opposite prevails when it comes to countries (or regions) with higher labor supply in relation to capital levels (Mundel, 1957). When such a disequilibrium arises it also entails the flow of migrants from countries with lower wages to countries with higher wages (Massey, 1988).

The migration systems theory also argues that migration contributes towards alteration and restructuring of the whole social and developmental circumstances at both destination and origin, or more specifically in concrete spaces where it takes place (De Haas, 2011). These changes would contribute to the formation of links between both receiving and sending countries, e.g. the existence of international trade and investment flows (Castles \& Miller, 2009).

Put differently, mobility factors flow i.e. trade (exports, imports), fdi, remittances that forms part of an international interaction between different countries usually also causes some discrepancies in their economic conditions. As a consequence, countries with more prosperous economies pull migrants from countries with less vibrant economies.
Thus, the migration systems theory argues that sending and receiving countries become a migration system with relatively strong flow of people, goods, capital, which is much more intensive than between any of these countries and countries pertaining to another system (Massey, 1988; Kurekova, 2011). Moreover, the same theory posits that since the appearance of the first migration the basic mechanisms driving further flows of migration and remittances between specific locations should normalize in the course of time, connecting and integrating the sending and receiving countries in a relatively stable manner (Castles \& Miller, 2009; Metelski \& Mihi-Ramirez, 2015).

Jennissen (2004) extended the international migration systems approach incorporating empirical evidence that clearly showed causalities between four groups of factors (economic, social, political and yet another group which he called: linkages between countries), of which several were mobility factors.

De Haas (2010) noted that circular cumulative causation theory and migration systems theory have very much in common. They both view the origin and destination as constituent parts of one societal and developmental context. In that sense, both sending and receiving ends contribute to the dynamics of migration. By comparison with migration systems theory the circular cumulative causation theory puts more emphasis on sending societies. The influence of migration processes on it is mostly negative. De Haas (2010) also accentuated the gap that arises between the receiving and sending economies in the form of income and welfare inequalities.

According to the circular cumulative causation theory once the process of migration is initiated (from whatever reason it would be) it then becomes the reason for a next migration wave (i.e. a continuation of migration processes). These flows would change socio-economic situation of sending countries so significantly, so that they would entail further migration flows, trade, fdi, remittances and so on. As a result, it leads to the emergence of sort of feedback loop between migration and its after-effects (Massey, 1988; De Haas, 2011).

Furthermore, when migration is already initialized for whatever reason, then the process continues and have even a tendency to worsen the disparities between receiving and sending countries which caused migration in the first place. In a nutshell, this consists of economies of scale that contribute to further enrichment of the core and impoverishment of the periphery. In that sense, both receiving and sending ends become polarized and a vicious circle of poverty is created in the periphery (De Haas, 2011).

From this perspective there are some positive effects (e.g. increased demand for agricultural products, raw materials trade or the effects of remittances), the overall repercussions (i.e. after-effects) are negative as the productivity and wealth at origin have a tendency to decrease (de Haas, 2010).

The theory of circular cumulative causation argues that multi-causality exists between migration main causes (i.e. variables). It is said, that any change of a variable causing migration also brings further changes of other variables due to the interlinkages between different actors (i.e. institutions) of migration. These changes occur only gradually otherwise they would bring a great deal of chaos. 
Moreover, once migration becomes operational the whole process has a tendency to perpetuate itself. In that sense it is kind of circular and cumulative process as it cycles its way to infinity (ad infinitum) (King, 2012).

The mobility factors. Causality and its effects

Linkages between emigration and mobility factors have positive and negative effects. According to the migration systems theory, international free trade reduces migration flows between labor-intensive and capitalintensive countries, as the latter import labor-intensive goods and thereby contribute to higher employment in the labor-intensive countries, bringing the net migration down. In turn, the flows of capital (or capital-intensive products) in the opposite direction counterbalance the consequences of both wage and unemployment differentials (Castles \& Miller, 2009; De Haas, 2011).

The flow of production and market factors (i.e. capital, labor and goods) makes the entire system more efficient and more profitable (Massey, Arango, Hugo, Kouaouci, Pellegrino \& Taylor, 1993). Since the mineral raw materials in rich countries begin to run out and the labor costs go up, companies start looking for mineral raw materials and lower labor costs overseas. This actually leads to a flow of goods and capital from the core to the peripheries (i.e. from Heartland to Rimland). As a natural consequence of that a migration of population in the opposite direction is triggered (Massey et al., 1993).

Zlotnik (1998) noticed that the flow of capital and labor usually takes place in two opposing directions. Central regions are in need for low skilled labor due to a drop in interest on jobs in manufacturing sector which, in turn, is caused by a structural change towards more serviced-based economy. In contrast, peripheries experience a drop in the demand for agricultural workforce which is the result of more capital-intensive economy, ever since the economy starts to import capital. The surplus of agricultural workforce is somehow forced to migrate to the central region in search for low-skilled jobs (in manufacture or service sector).

In that context, Jennissen (2004) studied former metropolitan states and their colonies, and came to the conclusion that the latter had certain competitive advantage with regard to terms of trade. Jennissen (2004) also stressed that the view of the world systems theory on international trade can be seen as controversial, as free trade is contemporarily thought to reduce income and employment disparities and therefore also migration.

Aubry et al. (2012) showed that according to the neoclassical theory trade reduces the scope for migration and vice versa. Trade helps to achieve price convergence, so it reduces the incentives for emigration. In turn, reducing price differentials affects the scope for trade.

Furthermore, Kurekova (2011) noted that international migration is a consequence of certain structural labor market disruptions that result from an increase in export of manufacturing and agriculture products and the flow of capital in the form of foreign direct investment running from developed to developing countries. Capital mobility is hence a crucial factor for the world system (Kurekova, 2011). However, capital is always somehow linked to labor mobility and they both are said to form two sides of the coin (De Haas, 2008).
Aubry et al. (2012) found that migration has a positive impact on fdi. Thus, a higher FDI in a country sending migrants leads to a higher emigration to a country that receives fdi. Also, capital simply moves in the directions that coincides with labor migrants' flow, i.e. labor force will settle where the salaries are higher. Therefore migration and_FDI help to achieve convergence between international labor demand and supply.

According to the same authors, emigration, especially when it comes to skilled migration, reduces the transaction costs of foreign sales, and therefore trade, FDI and migration can be regarded as complements (Aubry et al. 2012, p. 20). In this instance, emigrants constitute an important source of information with respect to foreign sales and international trade opportunities, encouraging FDI and trade (and more specifically encouraging export to those countries).

In addition, growing migration has implied an important source of finance trough remittances to many developing countries (Okodua \& Olayiwola, 2013). As it turns out, massive inflows of remittances can contribute to the appreciation of real exchange rate in receiving economies, reducing foreign trade competitiveness which in turn, deteriorates the trade balance (in receiving countries) via a reduction in exports of traded goods (Okodua \& Olayiwola, 2013, p. 135).

On the contrary, Bouhga-Hagbe (2004) and Rajan \& Subramanian (2005) argued that remittances help to improve trade deficit and an overvalued currency. Also, if remittances are intended to improve productivity, the negative effect can be mitigated (Okodua \& Olayiwola, 2013).

Moreover, Mamun (2010) found also the evidence showing positive consequences that remittances received exert on consumption, fdi, earnings related to export goods and poverty reduction.

Heckscher (1919) and Ohlin (1933) made a significant contribution to the literature in the field of migration. They started a completely new approach that was related to the exchange in international trade. Their findings were later further studied and disseminated by Samuelson (1948) what became known as the international trade theory. According to that concept migration is the effect of an exchange of production resources, and more strictly of capital and labor. This line of investigation was later continued by other authors (Markusen, 1983; Schiff, 1994; Taylor, 1996; Schiff, 2006).

It can also be understood that international trade is sort of complement to migration (Schiff, 1994; Taylor, 1996). Migrants flow from poorer countries to richer countries can be regarded as a direct result of international trade between countries. Compared to migration, capital resources usually flow in the opposite direction. The reason is that investors are looking for better opportunities for their capital and they find them in labor-intensive countries (i.e. poor countries). This in turn pushes wages higher in poor countries and reduces them in richer ones. Anyways, the wages in different countries shall equalize at some stage. However, in a short run any changes might be barely discernible. On the other hand, in a long run one might expect wages' harmonization to the extent that any differences will be noticeable. 
Here it is worth to mention the network migration theory that recognizes migrant social networks as an important force in explaining the perpetuity of international migration (Massey, 1988; Kurekova, 2011). This theory could explain the causes that perpetuate migration in time and space (when economic factors are balanced).

The network theory has very much in common with another conceptual approach, namely, the migration systems theory developed by Mabogunje (1970). De Haas (2008) noticed that both theories address the role that migration plays in affecting and altering the developmental space which is related with migration processes (de Haas, 2008). In that sense, migration exerts certain impact on economic, institutional, social and cultural characteristics of receiving and sending "ends".

Korgelli (1994) and Bijak (2010) indicated that domestic and international migration flow may be considered complements to a certain extent. In other words, migrants may either migrate from poorer regions of one country to richer regions of the same country or simply they can migrate abroad. In any event, the same mechanisms or the theory that stays behind these mechanisms may be used to justify both of these processes (Bijak, 2010). However, there also studies that prove the opposite (Stillwell et al., 1999; Bijak, 2010).

Kupiszewska (2005) and Stillwell et al. (2010) indicated the example of Poland and they showed that when prospective migrants are given a free choice they would always prefer to migrate internationally (though differences in regional wages would justify the opposite). The incentives must be of a different nature than economic because when migrating internationally people are usually exposed to greater barriers in comparison with domestic migration i.e. there are some cultural, linguistic and mental barriers involved.

Bijak (2010) aptly noted that in relation to European integration, the differences between internal and external migration have lost their importance or simply have blurred. It can be regarded as a consequence of the lack of borders and the freedom of movement for labor migrants. Today, countries can be perceived simply as larger regions. There are no binding restrictions (i.e. binding immigration quotas like before) that would under-mine this freedom, with a very few exceptions e.g. when someone is without means of support and is not working or is not seeking for a job, then he/she may be expelled from certain countries.

\section{Methodology}

The variables (emigration, trade balance, FDI and remittances paid) were cautiously selected taking into account various migration theories and conceptual frameworks. Further, the most recent years (1999-2014) were studied in order to provide the most actual (up-todate) picture with respect to migration processes.

Typically, there is lack of a single and unanimous definition with respect to migration phenomenon (Akkoyunlu, 2009; Mihi-Ramirez, Metelski \& Rudzionis, 2013).The most frequently referred definitions of immigration and emigration are provided by the Official Journal of the European Union (OJEU, 2007, p. 1) that defines the emigration/migration (EM) as "the action by which a person, having previously been usually resident in the territory of a Member State, ceases to have his or her usual residence in that Member State country for a period that is, or is expected to be, of at least 12 months".

The data of emigration is released by Eurostat (Eurostat, 2015a). Emigration is usually much harder to count than immigration (Jennissen, 2004; de Beer, 2010). Actually, it is much more difficult to count those who are leaving a country. Therefore an adjustment of inconsistencies with respect to data on migration was performed (de Beer et al., 2010).

Trade balance (TB) is defined as the difference between the monetary value of exports and imports of output in an economy over a certain period, measured in the currency of that economy (Eurostat, 2015b). The source of trade balance was obtained from the database of international trade in goods' statistics (Eurostat, 2015b).

Foreign direct investment (FDI) reflects "the objective of obtaining a lasting interest by an investor in one economy in an enterprise resident in another economy" (Eurostat, 2015c, p. 1). In this case we use data from the balance of payments released by Eurostat (2015c).

Remittances received (PRR) include all current transfers in cash or in kind between resident and nonresident individuals plus compensation of employees who are employed in an economy where they are not resident and of residents employed by nonresident entities (World Bank, 2006, p. 1). The data is obtained from the database of personal transfers and compensation of employees (Eurostat, 2015d).

This paper analyzes causality relationships between mobility factors using data that consist of annual observations for countries that lie in the important and well developed European region and that are closely related with each other, namely the Scandinavian and Baltic area countries (Sweden, Norway, Denmark, Finland, Lithuania, Latvia and Estonia). They all show different kind of mobility factors' relationships. A panel VAR model is developed to test for causalities between those mobility factors (Dolado \& Lütkepohl, 1996). The presence of cointegration is tested using the Fisher-Johansen cointegration test (Crowder, 2003).

Vector autoregression models (VAR) constitute an alternative to multivariate simultaneous equation models (Pesaran \& Shin \& Smith, 2001). Typically, all taken variables in a VAR model are assumed to be of endogenous character, though without imposing strong restrictions of the kind required to identify underlying structural parameters. VAR model serves as a method of modeling time-series.

The econometric procedure that is used in this study is the following:

1. Panel Unit Root detection

2. Fisher-Johansen Test of Cointegration

3 Development of panel VAR or VECM model which is dependent of the results of the Fisher-Johansen Test of Cointegration

4. Wald Test for checking coefficient restrictions (i.e. to detect causality)

First, we cannot run Johansen Cointegration test without making sure first that all taken variables are 
integrated of the same order. If our variables are nonstationary (as economic variables usually are) then we have to check their first differences, to make sure that we are dealing with the kind of variables that are integrated of the same order (Engle \& Granger, 1987).

Hence, we test for unit roots (for all our variables). First we check emigration variable (EM) (see Table 1 and 2).

Table 1

Emigration. Panel unit root test: Summary

\begin{tabular}{|l|c|c|c|c|}
\hline Method & Statistic & Prob.** & $\begin{array}{c}\text { Cross- } \\
\text { sections }\end{array}$ & Obs \\
\hline Null: Unit root (assumes common unit root process) \\
\hline Levin, Lin \& Chu t* & 0.99414 & 0.8399 & 7 & 105 \\
\hline Null: Unit root (assumes individual unit root process) \\
\hline ADF - Fisher Chi-square & 5.27314 & 0.9816 & 7 & 105 \\
\hline PP - Fisher Chi-square & 4.39559 & 0.9926 & 7 & 105 \\
\hline
\end{tabular}

** Probabilities for Fisher tests are computed using an asymptotic Chisquare distribution. All other tests assume asymptotic normality.

The variable EM is non-stationary so we check its "first difference".

Table 2

Emigration. Panel unit root test: first difference

\begin{tabular}{|l|c|c|c|c|}
\hline Newey-West automatic bandwidth selection and Bartlett kernel \\
\hline Method & Statistic & Prob.** & $\begin{array}{c}\text { Cross- } \\
\text { sections }\end{array}$ & Obs \\
\hline Null: Unit root (assumes common unit root process) \\
\hline Levin, Lin \& Chu t* & -9.49549 & 0.0000 & 7 & 97 \\
\hline Null: Unit root (assumes individual unit root process) \\
\hline ADF - Fisher Chi-square & 93.5006 & 0.0000 & 7 & 97 \\
\hline PP - Fisher Chi-square & 98.0063 & 0.0000 & 7 & 98 \\
\hline
\end{tabular}

** Probabilities for Fisher tests are computed using an asymptotic Chisquare distribution. All other tests assume asymptotic normality.

Its first difference turns out to be stationary (as we expected). Emigration variable is I(1). What does it mean? It is not stationary at level (it has unit root). However, When converted to first difference it becomes stationary (it does not have any unit root).

We repeat the same procedure with trade balance (TB), FDI and remittances received (PRR).

Trade Balance. Panel unit root test: first difference

\begin{tabular}{|l|c|c|c|c|}
\hline Method & Statistic & Prob.** & $\begin{array}{c}\text { Cross- } \\
\text { sections }\end{array}$ & Obs \\
\hline Null: Unit root (assumes common unit root process) \\
\hline Levin, Lin \& Chu t* & -1.84333 & 0.0326 & 7 & 100 \\
\hline Null: Unit root (assumes individual unit root process) \\
\hline ADF - Fisher Chi-square & 14.2771 & 0.4293 & 7 & 100 \\
\hline PP - Fisher Chi-square & 12.8236 & 0.5405 & 7 & 105 \\
\hline
\end{tabular}

** Probabilities for Fisher tests are computed using an asymptotic Chisquare distribution. All other tests assume asymptotic normality.

The results show that trade balance is $\mathrm{I}(0)$ meaning that tb variable is stationary. Hence, this variable is not good for our model, unless we apply the procedure developed by Pesaran et al. (2001) for testing cointegration between the variables that are not integrated at the same order. ARDL model approach described by Pesaran is the only way to find the cointegration among the variables having different orders $\mathrm{I}(0)$ and $\mathrm{I}(1)$ but keeping in mind none of the variable is stationary at $\mathrm{I}(2)$ (Pesaran et al., 2001).

To avoid econometric problems with our model we consider incorporating rather Export variable (EXP) into our model instead of the mentioned trade balance (TB).

Therefore, we test for a unit root for export variable (EXP). It is as follows (Table 4):

Table 4

Trade Balance. Panel unit root test: Summary

\begin{tabular}{|l|c|c|c|c|}
\hline Method & Statistic & Prob.** & $\begin{array}{c}\text { Cross- } \\
\text { sections }\end{array}$ & Obs \\
\hline Null: Unit root (assumes common unit root process) \\
\hline Levin, Lin \& Chu t* & 2.87697 & 0.9980 & 7 & 102 \\
\hline Null: Unit root (assumes individual unit root process) \\
\hline ADF - Fisher Chi-square & 1.39812 & 1.0000 & 7 & 102 \\
\hline PP - Fisher Chi-square & 0.49045 & 1.0000 & 7 & 105 \\
\hline
\end{tabular}

** Probabilities for Fisher tests are computed using an asymptotic Chisquare distribution. All other tests assume asymptotic normality.

The results show that export is a non-stationary variable. Then we test its first differences (Table 5).

Trade Balance. Panel unit root test: first difference

\begin{tabular}{|l|c|c|c|c|}
\hline Method & Statistic & Prob.** & $\begin{array}{c}\text { Cross- } \\
\text { sections }\end{array}$ & Obs \\
\hline Null: Unit root (assumes common unit root process) \\
\hline Levin, Lin \& Chu t* & -8.82356 & 0.0000 & 7 & 98 \\
\hline Null: Unit root (assumes individual unit root process) \\
\hline ADF - Fisher Chi-square & 85.7387 & 0.0000 & 7 & 98 \\
\hline PP - Fisher Chi-square & 90.8785 & 0.0000 & 7 & 98 \\
\hline
\end{tabular}

** Probabilities for Fisher tests are computed using an asymptotic Chisquare distribution. All other tests assume asymptotic normality.

As it turns out the first difference of EXP variable is stationary. Export is then I(1).

All in all, the Levin, Lin \& Chu t tests and Fisher tests (both ADF \& PP) confirm that emigration (EM), export (EXP01), FDI and remittances received (PRR) are all integrated of the same order I(1).

As a next step we run the Fisher-Johansen Test of Cointegration for all variables (see Table 6 for the case of EM and EXP) and its results confirm that none of the mobility variables that we employ (whether it would be export, FDI or remittances received) is cointegrated with emigration). We cannot reject the null hypothesis that our two variables are not cointegrated (Crowder, 2003)

Therefore it may be concluded that there is no indication of a long run associationship between emigration and any of the remaining mobility variables.

Table 6

Johansen Cointegration Test. Emigration and Exports

\begin{tabular}{|c|c|c|c|c|}
\hline \multicolumn{5}{|c|}{ Unrestricted Cointegration Rank Test (Trace and Maximum } \\
Eigenvalue) \\
$\begin{array}{c}\text { Hypothesized } \\
\text { No. of CE(s) }\end{array}$ & $\begin{array}{c}\text { Fisher } \\
\text { Stat.* } \\
\text { (from } \\
\text { trace test) }\end{array}$ & Prob. & $\begin{array}{c}\text { Fisher Stat** } \\
\text { (from max- } \\
\text { eigen test) }\end{array}$ & Prob. \\
\hline None & 20.13 & 0.1261 & 20.12 & 0.1264 \\
\hline At most 1 & 9.855 & 0.7727 & 9.855 & 0.7727 \\
\hline$*$ Probabilities are computed using asymptotic Chi-square distribution. \\
\hline Individual cross section results & \\
\hline
\end{tabular}


Antonio Mihi-Ramirez, Eduardo Cuenca-Garcia, Maria Jose Miranda-Martel. Is There a Causality Between Emigration ...

\begin{tabular}{|c|c|c|c|c|}
\hline Cross Section & $\begin{array}{l}\text { Trace Test } \\
\text { Statistics }\end{array}$ & Prob.** & $\begin{array}{c}\text { Max-Eigen } \\
\text { Test } \\
\text { Statistics }\end{array}$ & Prob.** \\
\hline \multicolumn{5}{|c|}{ Hypothesis of no cointegration } \\
\hline 1 & 14.8168 & 0.5898 & 9.4395 & 0.6786 \\
\hline 2 & 12.7884 & 0.7545 & 9.8056 & 0.6396 \\
\hline 3 & 28.4379 & 0.0235 & 24.6521 & 0.0078 \\
\hline 4 & 15.2762 & 0.5516 & 8.5967 & 0.7652 \\
\hline 5 & 17.5671 & 0.3738 & 12.7163 & 0.3514 \\
\hline 6 & 21.5980 & 0.1554 & 12.7568 & 0.3480 \\
\hline 7 & 22.4049 & 0.1273 & 16.2474 & 0.1349 \\
\hline \multicolumn{5}{|c|}{ Hypothesis of at most 1 cointegration relationship } \\
\hline 1 & 5.3773 & 0.5431 & 5.3773 & 0.5431 \\
\hline 2 & 2.9828 & 0.8786 & 2.9828 & 0.8786 \\
\hline 3 & 3.7858 & 0.7729 & 3.7858 & 0.7729 \\
\hline 4 & 6.6795 & 0.3791 & 6.6795 & 0.3791 \\
\hline 5 & 4.8508 & 0.6179 & 4.8508 & 0.6179 \\
\hline 6 & 8.8412 & 0.1904 & 8.8412 & 0.1904 \\
\hline 7 & 6.1575 & 0.4406 & 6.1575 & 0.4406 \\
\hline
\end{tabular}

**MacKinnon-Haug-Michelis (1999) p-values

Subsequently, we develop a panel VAR model, both fixed and random and try to figure out whether there are some short term causalities between the variables that are subject of our study. In total, we establish 6 models (two for each pair of variables assuming that emigration is always included and reflecting the possibility of the existence of bidirectional relationships). They can be expressed as follows (with the lag order in parentheses):

(1) $\mathrm{EM}=\mathrm{C}+\mathrm{EM}(-1)+\mathrm{EM}(-2)+\mathrm{EXP}(-1)+\mathrm{EXP}(-2)$

(2) $\mathrm{EXP}=\mathrm{C}+\mathrm{EXP}(-1)+\mathrm{EXP}(-2)+\mathrm{EM}(-1)+\mathrm{EM}(-2)$

(3) $\mathrm{EM}=\mathrm{C}+\mathrm{EM}(-1)+\mathrm{EM}(-2)+\mathrm{FDI}(-1)+\mathrm{FDI}(-2)$

(4) $\mathrm{FDI}=\mathrm{C}+\mathrm{FDI}(-1)+\mathrm{FDI}(-2)+\mathrm{EM}(-1)+\mathrm{EM}(-2)$

(5) $\mathrm{EM}=\mathrm{C}+\mathrm{EM}(-1)+\mathrm{EM}(-2)+\mathrm{PRR}(-1)+\mathrm{PRR}(-2)$

(6) $\mathrm{PRR}=\mathrm{C}+\mathrm{PRR}(-1)+\mathrm{FDI}(-2)+\mathrm{EM}(-1)+\mathrm{EM}(-2)$

Next, we perform the Hausman Test for model (1) to check which model specification fits the best our data (Fixed effects model or Random effects model) and then we also run the Wald test so that to detect causalities (see Table 7, 8 and 9).

Table 7

Fixed Effects Model (1)

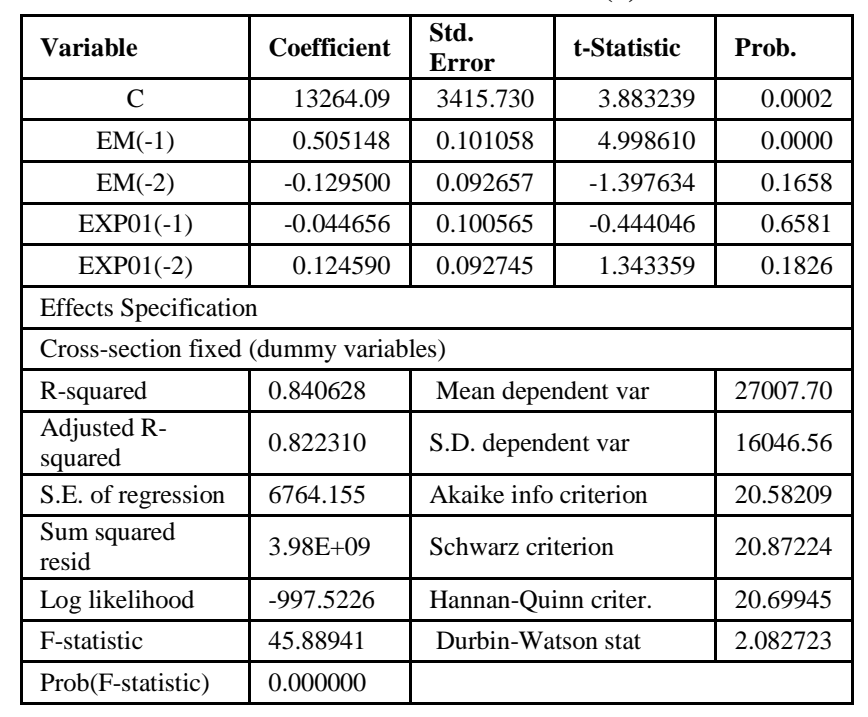

Random Effect Model (1)

\begin{tabular}{|c|c|c|c|c|}
\hline Variable & Coefficient & $\begin{array}{l}\text { Std. } \\
\text { Error }\end{array}$ & t-Statistic & Prob. \\
\hline $\mathrm{C}$ & 3441.849 & 1387.954 & 2.479801 & 0.0149 \\
\hline EM(-1) & 0.817788 & 0.087496 & 9.346590 & 0.0000 \\
\hline $\mathrm{EM}(-2)$ & 0.043134 & 0.087594 & 0.492429 & 0.6236 \\
\hline EXP01(-1) & -0.114911 & 0.089335 & -1.286287 & 0.2015 \\
\hline EXP01(-2) & 0.138008 & 0.091033 & 1.516014 & 0.1329 \\
\hline \multicolumn{5}{|l|}{ Effects Specification } \\
\hline & & & S.D. & Rho \\
\hline \multicolumn{3}{|l|}{ Cross-section random } & 0.000000 & 0.0000 \\
\hline \multicolumn{3}{|l|}{ Idiosyncratic random } & 6764.155 & 1.0000 \\
\hline \multicolumn{5}{|l|}{ Weighted Statistics } \\
\hline R-squared & 0.769602 & \multicolumn{2}{|c|}{ Mean dependent var } & 27007.70 \\
\hline $\begin{array}{l}\text { Adjusted R- } \\
\text { squared }\end{array}$ & 0.759692 & \multicolumn{2}{|c|}{ S.D. dependent var } & 16046.56 \\
\hline S.E. of regression & 7866.212 & \multicolumn{2}{|c|}{ Sum squared resid } & $5.75 \mathrm{E}+09$ \\
\hline F-statistic & 77.66234 & \multicolumn{2}{|c|}{ Durbin-Watson stat } & 2.028954 \\
\hline Prob(F-statistic) & 0.000000 & & & \\
\hline \multicolumn{5}{|l|}{ Unweighted Statistics } \\
\hline R-squared & 0.769602 & \multicolumn{2}{|c|}{ Mean dependent var } & 27007.70 \\
\hline Sum squared resid & $5.75 \mathrm{E}+09$ & \multicolumn{2}{|c|}{ Durbin-Watson stat } & 2.028954 \\
\hline
\end{tabular}

Hausman Test (1)

\begin{tabular}{|l|c|r|r|}
\hline Test Summary & $\begin{array}{c}\text { Chi-Sq. } \\
\text { Statistic }\end{array}$ & $\begin{array}{c}\text { Chi-Sq. } \\
\text { d.f. }\end{array}$ & Prob. \\
\hline Cross-section random & 38.377181 & 4 & 0.0000 \\
\hline
\end{tabular}

** WARNING: estimated cross-section random effects variance is zero.

Cross-section random effects test comparisons:

\begin{tabular}{|c|c|c|c|c|}
\hline Variable & Fixed & Random & Var(Diff.) & Prob. \\
\hline $\operatorname{EM}(-1)$ & 0.505148 & 0.817788 & 0.002557 & 0.0000 \\
\hline $\operatorname{EM}(-2)$ & -0.129500 & 0.043134 & 0.000913 & 0.0000 \\
\hline EXP01(-1) & -0.044656 & -0.114911 & 0.002133 & 0.1282 \\
\hline EXP01(-2) & 0.124590 & 0.138008 & 0.000315 & 0.4494 \\
\hline \multicolumn{5}{|c|}{ Cross-section random effects test equation: } \\
\hline Variable & Coefficient & Std. Error & t-Statistic & Prob. \\
\hline $\mathrm{C}$ & 13264.09 & 3415.730 & 3.883239 & 0.0002 \\
\hline $\mathrm{EM}(-1)$ & 0.505148 & 0.101058 & 4.998610 & 0.0000 \\
\hline $\operatorname{EM}(-2)$ & -0.129500 & 0.092657 & -1.397634 & 0.1658 \\
\hline EXP01(-1) & -0.044656 & 0.100565 & -0.444046 & 0.6581 \\
\hline \multirow[t]{2}{*}{ EXP01(-2) } & 0.124590 & 0.092745 & 1.343359 & 0.1826 \\
\hline & \multicolumn{2}{|c|}{ Effects Specification } & & \\
\hline \multicolumn{5}{|c|}{ Cross-section fixed (dummy variables) } \\
\hline R-squared & 0.840628 & \multicolumn{2}{|c|}{ Mean dependent var } & 27007.70 \\
\hline $\begin{array}{l}\text { Adjusted R- } \\
\text { squared }\end{array}$ & 0.822310 & \multicolumn{2}{|c|}{ S.D. dependent var } & 16046.56 \\
\hline S.E. of regression & 6764.155 & \multicolumn{2}{|c|}{ Akaike info criterion } & 20.58209 \\
\hline $\begin{array}{l}\text { Sum squared } \\
\text { resid }\end{array}$ & $3.98 \mathrm{E}+09$ & \multicolumn{2}{|c|}{ Schwarz criterion } & 20.87224 \\
\hline Log likelihood & -997.5226 & \multicolumn{2}{|c|}{ Hannan-Quinn criter. } & 20.69945 \\
\hline F-statistic & 45.88941 & \multicolumn{2}{|c|}{ Durbin-Watson stat } & 2.082723 \\
\hline Prob(F-statistic) & 0.000000 & & & \\
\hline
\end{tabular}

Hausman test confirms that FE is the right model (as $\mathrm{p}$-value is <.05).

In order to detect causalities we run the Wald test (Table 10). 
Table 10

Wald test (1)

\begin{tabular}{|l|c|c|c|}
\hline Test Statistic & Value & df & Probability \\
\hline F-statistic & 1.483502 & $(2.87)$ & 0.2325 \\
\hline Chi-square & 2.967004 & 2 & 0.2268 \\
\hline Null Hypothesis: C(4)=C(5)=0 & \multicolumn{1}{|l}{} \\
\hline Null Hypothesis Summary: & Value & Std. Err. \\
\hline Normalized Restriction (=0) & -0.044656 & 0.100565 \\
\hline $\mathrm{C}(4)$ & 0.124590 & 0.092745 \\
\hline $\mathrm{C}(5)$ &
\end{tabular}

Restrictions are linear in coefficients.

As its associated p-value is >.05 we can then conclude that there is no causality running from export to emigration.

We repeat the same procedure for remaining models (2), (3), (4), (5) and (6). What we find out is that there is only one causality running from remittances received to emigration (as the p-value associated with F-statistic is less than .05).

\section{Discussion}

Taking different mobility variables (emigration, trade balance, export, fdi, remittances received), and making sure first that they were all integrated of the same order we tested for cointegration between emigration and the remaining mobility variables. As it turned out, they were not cointegrated, and as such, we could not perform the error correction models and we concluded that there is no long run associationship between emigration and export, FDI and remittances received. The relationship between the above-mentioned variables could not be done through the use of vector error correction models (VECMs) due to the lack of cointegration between variables, and we had therefore to apply vector autoregression models (VARs). Once we established appropriate VAR equations we sought for causalities, spotting only one such causality, namely the causality running from remittances received to emigration.

On the basis of these results, it may be concluded that there is certain interaction between some mobility factors, though they cannot be considered as substitutes. In a sense, emigration, trade, FDI and remittances received can be interlinked, though only in temporal and particular cases.

All in all, the results add further evidence to the Heckscher-Ohlin approach in that mobility factors are complements (Markusen, 1983). However, our results confirm the existence of causality only in the case of emigration and remittances received in the short run.

Remittances received can be perceived as contributing to an initial or more massive migration in the short run, however, in the long run emigration could be explained by other reasons. According to the network migration and the migration systems theories the incentives to migrate can be related to better expectations and mi-grant networks.

\section{Conclusion}

The reasons and implications of the interaction between emigration, trade balance, FDI and remittances were discussed in several theoretical approaches such as: the neo-classical economic migration theory, the migration systems theory, circular cumulative causation theory and the Heckscher-Ohlin conceptual framework. Also, several empirical works analyzed the impact of trade balance, FDI and remittances on emigration or vice versa (De Haas, 2011). However, the question whether emigration and other mobility factors (trade balance, FDI and remittances) can be considered substitutes (in a short or long run) has hitherto not been so evident.

Our results for the group of seven Baltics and Scandinavian countries (countries that are politically, economically and geographically close to each other), which also have different kind of mobility factors' relationships, showed that there is only one causality in the short run, namely when it comes to emigration and remittances received. Our results confirmed that there was no associationship between emigration and the rest of mobility factors, in the long run, and in the short run we found causality only for emigration and remittances received.

As there is no obvious evidence which proves connections between emigration and export or FDI, therefore there is all the more reason why we should stress the relevance of between emigration and remittances received.

In a sense, these results add certain evidence to the Heckscher-Ohlin approach that migration and some other mobility factors might be complements. As it turned out in our research, the case of emigration and remittances received seems to confirm it, though only in the short term. Therefore, capital flows (in the form of remittances received) might be perceived as fostering emigration, but the effect of remittances is limited because, the level of development is increased and the imbalances are reduced.

In this sense, the network migration and the migration systems theories can help to explain the persistence of international migration processes over time, even when the initial migration incentives diminish or cease to exist (Jennisen, 2004). We avail ourselves of the opinion held by Jennissen (2004) and provide evidence that remittances received (PRR) help to trigger an initial or more massive migration in a first step, and subsequently, the persistence of imbalances or migrants networks contribute to further migration.

Taking into account the findings of Mamun (2010) and Zhua et al. (2014), we can conclude that in this very case more efficient migration policy in a short run would be to strongly promote the use of such remittances in activities related to productivity improvement of any sector, in order to avoid higher migration and also to reduce the poverty in sending countries. However, the only policies that work in a long term are the ones that promote families' reunifications because they largely reinforce migrant networks (Massey et al., 1993). 


\section{References}

Aubry, A., Kugler, M., \& Rapoport, H. (2012). Migration, FDI and the Margins of Trade. Boston: Center for International Development, Harvard University; Barilan University and University of Lille.

Akkoyunlu, S. (2009). Trade, Aid, Remittances and Migration. Working Paper No. 229. Zurich: Swiss Economic Institute; European University Institute.

Bijak, J. (2010). Forecasting international migration in Europe: a Bayesian view. The Springer Series on Demographic Methods and Population Analysis. Springer Science + Business Media B.V, 24.

Bouhga-Hagbe, J. (2004). A Theory of Workers' Remittances with an Application to Morocco. IMF Working Paper 04/194, Washington D. C., International Monetary Fund. http://dx.doi.org/10.5089/9781451859898.001

Castles, S., \& Miller, M. J. (2009). The Age of Migration: International Population Movements in the Modern World, Basingstoke: Palgrave Macmillan (4th edition).

Crowder, W. J. (2003). Panel estimates of the Fisher effect. University of Airlington, Department of Economics.

De Haas, H. (2008). Migration and development. A theoretical perspective. International Migration Institute Working Paper, University of Oxford, 9.

De Haas, H. (2010). Migration and Development: A Theoretical Perspective. International Migration Review, 44, 227264. http://dx.doi.org/10.1111/j.1747-7379.2009.00804.x

De Beer, J., Raymer, J., van der Erf, R., \& van Wissen, L. (2010). Overcoming the Problems of Inconsistent International Migration data: A New Method Applied to Flows in Europe. Journal of Population, 26 (1), $459-481$. http://dx.doi.org/10.1007/s10680-010-9220-z

De Haas, D. (2011). The determinants of international Migration: Conceptualising policy, origin and destination effects. Working paper no. 32, Oxford: International Migration Institute, University of Oxford.

Dolado, J. J. H., \& Lutkepohl (1996). Making Wald tests work for cointegrated VAR systems. Econometric Re-views, 15, 369-386. http://dx.doi.org/10.1080/07474939608800362

Engle, R. E., \& Granger, C. W. J. (1987). Co-integration and Error Correction: Representation, Estimation and Testing. Econometrica, 55(2), 251-276. http://dx.doi.org/10.2307/1913236

Eurostat. (2015a). Migration and migrant population statistics. Migration and Migrant population statistics. Luxemburg: Eurostat. Available online: http://ec.europa.eu/eurostat/statisticsexplained/index.php/Migration_and_migrant_ population_statistics, Retrieved on 05.01.2016.

Eurostat (2015b). International trade in goods statistics. Available on line: http://ec.europa.eu/eurostat/web/internationaltrade/data/database Retrieved on 15.01.2016

Eurostat (2015c). Balance of payments - International transactions (bop). Available on line: http://ec.europa.eu/eurostat/ web/balance-of-payments/data/database Retrieved on 15.01.2016

Eurostat (2015d). Personal transfers and compensation of employees. Available on line: http://ec.europa.eu/eurostat/ web/balance-of-payments/data/database Retrieved on 15.01.2016

Heckscher, E. (1919). The Effect of Foreign Trade on the Distribution of Income. Ekonomisk Tidskrift, 21, $497-512$.

Jennissen, R. P. W. (2004). Macro-Economic Determinants of International Migration in Europe. Amsterdam: Dutch University Press.

King, R. (2012). Theories and Typologies of Migration: An Overview and a Primer. Willy Brandt Working Papers in International Migration and Ethnic Relations, Malmo University, 3(12).

Korgelli, P. (1994). On interrelations between internal and international migration. The European Journal of Social Science Research, (7)2, 151-163. http://dx.doi.org/10.1080/13511610.1994.9968397

Kupiszewska, D., \& Nowok, B. (2005). Comparability of statistics on international migration flows in the European Union. Working Paper, 7. Central European Forum for Migration and Population Research.

Kurekova, L. (2011). Theories of migration: Conceptual review and empirical testing in the context of the EU East-West flows. Interdisciplinary conference on Migration. Economic Change, Social Challenge. April 6-9, University College, London, Central European University.

Mabogunje, A. L. (1970). Systems Approach to a Theory of Rural-Urban Migration. Geographical Analysis, 2 , 1-18. http://dx.doi.org/10.1111/j.1538-4632.1970.tb00140.x

Mamun, K. A. (2010). Mundell, R. (1957). International Trade and Factor Mobility. The American Economic Review, 47 (3), 321-335. Journal of Business Strategies, 27(1), 29-52.

Markusen, J. R. (1983). Factor Movements and Commodity Trade as Complements. Journal of International Economics, 14, 341-356. http://dx.doi.org/10.1016/0022-1996(83)90009-0

Markusen, J., \& Venables, A. (1997). The Role of the Multinational Firm in the Wage-Gap Debate. Review of International Economics, 5, 435-451. http://dx.doi.org/10.1111/1467-9396.00068 
Massey, D. S. (1988). Economic Development and International Migration in Comparative Perspective. Population and Development Review, 14 (3), 383-413. http://dx.doi.org/10.2307/1972195

Massey, D. S., Arango, J., Hugo, G., Kouaouci, A., Pellegrino, A., \&Taylor, J. E. (1993). Theories of International Migration: a Review and Appraisal. Population and Development Review, 19 (3), $431-466$. http://dx.doi.org/10.2307/2938462

Metelski, D., \& Mihi-Ramirez, A. (2015). The Economic Impact of Remittances and Foreign Trade on Migration. Granger-Causality approach. Inzinerine Ekonomika-Engineering Economics, 26(4), 364-372. http://dx.doi.org/10. 5755/j01.ee.26.4.12464

Mihi, A., Metelski, D., \& Rudzionis, A. (2013). Influence of earnings and unemployment on economic migration flow. Analysis of Lithuania and Spain. Vilnius: International Scientific Conference "Whither Our Economies".

Mundell, R. (1957). International Trade and Factor Mobility. The American Economic Review, 47 (3), $321-335$.

Okodua, H., \& Olayiwola, W. K. (2013). Migrant Workers' Remittances and External Trade Balance in Sub-Sahara African Countries. International Journal of Economics and Finance, 5(3), 134-142. http://dx.doi.org/10. 5539/ijef.v5n3p134

Ohlin, B. (1933). Interregional and International Trade. Cambridge, MA: Harvard University Press.

Pesaran, M. H., Shin, Y., \& Smith, R. J. (2001). Bounds testing approaches to the analysis of level relationships. J. Appl. Econ, 16, 289-326. http://dx.doi.org/10.1002/jae.616

Rajan, R., \& Subramanian, A. (2005). What Undermines Aid's Impact on Growth? IMF Working Paper 05/126, Washington D. C., International Monetary Fund.

Pesaran, M. H., Shin, Y., \& Smith, R. J. (2001). Bounds testing approaches to the analysis of level relationships. Journal of Applied Economics, 16, 289-326. http://dx.doi.org/10.1002/jae.616

Samuelson, P. (1948). International Trade and the Equalization of Factor Prices. Economic Journal, 58, 596, in HeckscherOhlin model (230), 163-84

Sanderson, M., \& Kentor, J. (2008). Foreign Direct Investment and International Migration: A Cross-National Analysis of Less-Developed Countries. International Sociology, 23, 1985-2000. http://dx.doi.org/10.1177/0268580908090726

Schiff, M. (1994). How trade, aid and remittances affect international migration. Policy Research Working Paper, the World Bank International Economics Department, International Trade Division, November 1994.

Stillwell, J. C. H., Eyre, H., \& Rees, P. H. (1999). Regional international migration and interregional migration within the European Union: a feasibility study. Research report for the ERDF Study 98/00/27/174. Leeds: University of Leeds.

Taylor, J. E. (1996). Development Strategy, Employment and Migration: Insights from Models. Paris: OECD.

World Bank. (2006). Global Economic Prospects. World Bank publications. Washington, DC.

Zhua, Y, Wub, Z., Pengc, L., \& Shengd, L. (2014). Where did all the remittances go? Understanding the impact of remittances on consumption patterns in rural China. Applied Economics, 46(12), 1312-1322. http://dx.doi.org/10. 1080/00036846.2013.872764

Zlotnik, H. (1998). The theories of international migration. Conference on International Migration: Challenges for European Populations, Bari, Italy, 25-27 June.

The article has been reviewed.

Received in March, 2016; accepted in June, 2016. 